\title{
Preferensi Masyarakat terhadap Ruang Kota sebagai Tempat Relaksasi
}

\author{
Mutia Ayu Cahyaningtyas ${ }^{1}$, Hanson E. Kusuma² \\ ${ }^{1}$ Program Studi Magister Arsitektur, SAPPK, Institut Teknologi Bandung \\ ${ }^{2}$ Kelompok Keahlian Perancangan Arsitektur, SAPPK, Institut Teknologi Bandung \\ mutia.cahyaningtyas@gmail.com
}

\begin{abstract}
ABSTRAK
Masyarakat yang tinggal di daerah perkotaan memiliki kecenderungan lebih tinggi untuk mengalami stres dibandingkan masyarakat yang tinggal di pedesaan. Tingkat stres yang tinggi dapat dicegah dan dikurangi melalui pengadaan ruang kota sebagai tempat relaksasi. Perencanaan ruang kota harus mempertimbangkan dan melibatkan keinginan masyarakat sebagai calon pengguna untuk memperoleh hasil yang maksimal. Penelitian ini bertujuan untuk mengetahui preferensi masyarakat terhadap ruang kota yang ingin dikunjungi dalam rangka relaksasi diri. Penelitian dilakukan melalui pendekatan grounded theory dengan metode kualitatif yang bersifat eksploratif. Pengumpulan data dilakukan melalui penyebaran kuesioner daring yang bersifat terbuka (open-ended) dan pemilihan sampel secara bebas (non-random sampling). Data yang diperoleh dianalisis dengan analisis isi yang dilakukan dalam tiga tahapan open coding, axial coding, dan selective coding. Temuan menunjukkan terdapat enam aspek yang menjadi preferensi masyarakat terhadap ruang kota sebagai tempat relaksasi, yaitu nuansa alam, kelengkapan fasilitas, ketenangan, suasana, aksesibilitas, dan kualitas ruang. Penelitian ini diharapkan dapat mengeksplorasi potensi baru dalam perencanaan ruang kota sesuai dengan keinginan dan karakter masyarakatnya.
\end{abstract}

Kata kunci: preferensi, relaksasi, ruang kota, stres

\section{ABSTRACT}

People who live in urban areas tend to have a higher stress level than those who live in rural areas. Level of stress can be prevented and diminished through the establishment of urban relaxation spaces within the city. Urban city planning needs to consider citizens' preferences as potential users to obtain the maximum result. This study aims to determine the characteristics of preferred urban relaxation spaces within the city. The research was conducted through a grounded theory approach and exploratory qualitative method. Data collection was carried out based on the open-ended online survey questionnaire with a non-random sampling technique. Data was then analyzed by content analysis in three stages: open coding, axial coding, and selective coding. The finding shows that there are six aspects of preferred urban relaxation spaces: the sense of nature, facilities, tranquility, ambience, accessibility, and quality of space. Research is expected to explore new potentials in urban planning in accordance with the characteristics of its citizens.

Keywords: preference, relaxation, urban space, stress

\section{Pendahuluan}

Fenomena urbanisasi didorong oleh adanya persepsi masyarakat terhadap kota sebagai tempat potensial untuk tinggal dan mencari pekerjaan. Perkembangan urbanisasi ini memicu pertumbuhan pesat terhadap tingkat kepadatan penduduk di area perkotaan (Peen, 2010). Dye (2008) menyatakan saat ini lebih dari setengah populasi penduduk 
dunia tinggal di area perkotaan. Data United Nation Department of Economic and Social Affairs 2018 juga menyebutkan bahwa pertumbuhan ini diprediksi akan terus meningkat mencapai $66 \%$ pada tahun 2050 . Tingginya populasi penduduk di perkotaan menjadikan kesehatan lingkungan sebagai salah satu aspek prioritas yang perlu diperhatikan dalam perencanaan dan pengelolaan wilayah kota.

World Health Organization mendefinisikan kesehatan lingkungan sebagai keadaan kesejahteraan psikis, fisik, dan sosial dari masyarakat yang tinggal di dalamnya. Kondisi lingkungan binaan merupakan salah satu faktor yang mempengaruhi kesehatan psikis penduduknya, khususnya terhadap tingkat stres individu. Gruebner (2017) mengungkapkan bahwa risiko terjadinya penyakit psikis memiliki angka lebih tinggi pada area perkotaan dibandingkan pedesaan. Hal ini juga dipertegas dalam penelitian Adli (2011) yang menunjukkan bahwa penduduk kota memiliki risiko 20\% lebih tinggi terkena gangguan kecemasan (anxiety disorders) dan 40\% lebih tinggi terkena gangguan mood (mood disorders) dibandingkan penduduk desa.

Stres merupakan suatu reaksi saat seseorang merasakan ketegangan baik secara fisik maupun psikologis sebagai respon terhadap stimulus yang dianggap berpotensi mengancam dirinya. Menurut Ellison (1992), tingginya tingkat stres masyarakat perkotaan disebabkan oleh banyaknya sumber stres dalam kota yang dapat dikategorikan menjadi: gaya hidup, stimulus yang berlebih, kebutuhan psikospiritual, faktor sosial-psikologikal, faktor lingkungan, dan faktor biologikal. Sementara Fehr (2016) menyatakan bahwa sumber stres masyarakat perkotaan memiliki keterkaitan erat dengan jumlah populasi, sistem, serta dinamika lingkungan di dalam kota.

Penataan ruang kota sebagai lingkungan restorasi merupakan salah satu upaya untuk mengurangi tingkat stres masyarakat perkotaan. Hal ini dikarenakan tingkah laku manusia dan lingkungan merupakan hubungan dua arah yang saling menentukan dan tidak dapat terpisah satu dengan lainnya. Penciptaan lingkungan yang baik secara langsung dikatakan dapat mempengaruhi perilaku manusia di dalamnya. Dijkstra (2009) dalam hal ini juga menyatakan bahwa efek fisiologis dari lingkungan sangat mempengaruhi hasil penyembuhan stres psikologis.

Attention Restoration Theory mengungkapkan bahwa lingkungan restoratif memiliki kemampuan untuk mengembalikan fungsi kognitif dan memulihkan kelelahan pada individu. Efek restoratif ini dapat dicapai diantaranya dengan keluar dari rutinitas keseharian (being away), ketertarikan pada suatu hal (fascination), kualitas lingkungan yang koheren (extent), dan keterlibatan pada kegiatan yang sesuai dengan diri (compability) (Kaplan, 1995). Namun, Faehnle (2014) menyatakan bahwa setiap individu memiliki kecenderungan restorasi yang berbeda sehingga perbedaan tata lingkungan dapat memberikan efek restorasi yang berbeda pula. Penelitian ini bertujuan untuk mengeksplorasi preferensi masyarakat yang tinggal di perkotaan terhadap ruang yang dianggap paling efektif sebagai tempat relaksasi. Penelitian diharapkan menghasilkan pengetahuan tentang tempat-tempat dan kegiatan relaksasi yang dapat diterapkan dalam perencanaan atau perancangan kota.

\section{Bahan dan Metode}

Penelitian dilakukan menggunakan pendekatan grounded theory dengan metode kualitatif yang bersifat eksploratif. Menurut Creswell (2007), grounded theory merupakan suatu metode penelitian kualitatif dengan tujuan untuk menghasilkan teori dan penjelasan umum dari sebuah fenomena berdasarkan informasi yang diperoleh dari responden. Informasi berupa data tersebut kemudian dianalisis, ditafsirkan, dan disusun menjadi sebuah model hipotesis. Dalam penelitian ini, data yang diperoleh berupa informasi mengenai aspek-aspek yang menjadi preferensi responden tentang ruang kota sebagai tempat relaksasi. 
Pengumpulan data dilakukan melalui penyebaran kuesioner daring dengan metode pemilihan sampel non-random sampling berupa teknik snowball sampling. Teknik snowball sampling merupakan proses pemilihan sampel dengan memanfaatkan jaringan. Pemilihan sampel dimulai dari beberapa individu dalam suatu grup secara bebas. Setelah data diperoleh, sampel tersebut kemudian memilih beberapa individu lain dalam grup yang berbeda untuk menjadi sampel berikutnya. Proses tersebut terus berlanjut hingga jumlah target sampel tercapai. Kuesioner daring yang dibagikan bersifat terbuka (openended). Responden diminta untuk menjawab secara bebas dan seluas-luasnya tentang pertanyaan yang diajukan tanpa dibatasi. Melalui hal ini diharapkan jawaban yang akan didapatkan sesuai dengan hal yang dirasakan dan preferensi responden terkait ruang kota sebagai tempat relaksasi.

Data yang diperoleh melalui kuesioner daring yang dibagikan secara bebas berasal dari 107 responden dengan rincian 47 orang laki-laki dan 60 orang perempuan. Usia responden berkisar antara 17 tahun hingga 56 tahun. Tingkat pendidikan akhir mulai dari SMA hingga S3. Jenis pekerjaan terbagi menjadi tiga kategori yaitu pelajar atau mahasiswa sebanyak 59 orang, bekerja 42 orang, dan tidak bekerja sebanyak 6 orang. Responden berasal dari beberapa kota berbeda di Indonesia dengan rincian lama waktu tinggal berkisar 4 tahun hingga 50 tahun.

Data yang diperoleh melalui kuesioner daring kemudian dianalisis dengan menggunakan tiga tahap metode analisis data isi (content analysis), yaitu open coding, axial coding, dan selective coding (Creswell, 2007; Corbin, 2008). Tahap open coding merupakan tahap pendefinisian dan pengidentifikasian kata kunci yang diperoleh dari keseluruhan jawaban responden. Pada tahap ini, kata kunci yang memiliki kedekatan makna atau sifat dikelompokkan ke dalam kategori yang sama. Hasil pengelompokan kategori tersebut kemudian disajikan dalam bentuk diagram analisis distribusi. Tahap axial coding merupakan tahap eksplorasi hubungan korespondensi antar kategori. Sementara tahap selective coding merupakan tahap penyusunan model hipotesis berdasarkan hasil hubungan antar kategori pada tahap axial coding.

\section{Hasil dan Diskusi}

\subsection{Karakteristik Tempat Relaksasi}

Pada tahap awal analisis isi, dilakukan open coding untuk mengidentifikasi katakata kunci dari keseluruhan data teks jawaban responden. Beberapa contoh open coding yang diperoleh dari jawaban responden tentang alasan pemilihan ruang kota sebagai tempat relaksasi dapat diamati pada kutipan berikut.

"Mall Kelapa Gading, karena malnya tidak begitu luas, tetapi nyaman dan bersih, serta jaraknya dekat dari rumah." (Responden no 63)

"Lapangan golf, karena tempat terbuka dan hijau dengan lanskap yang bagus dan terawat." (Responden no 65)

Berdasarkan deskripsi tersebut, ditentukan beberapa kata kunci yang mewakili jawaban responden seperti "tidak luas", "nyaman", "bersih", "dekat dari rumah", "ruang terbuka", "hijau", dan "terawat".

Temuan kata-kata kunci hasil open coding kemudian dikelompokkan menjadi beberapa kategori. Terdapat enam kategori karakteristik ruang kota sebagai tempat relaksasi, yaitu aksesibilitas, nuansa alam, kelengkapan fasilitas, suasana, ketenangan, dan kualitas ruang. Hasil pengkategorian open coding dapat diamati pada Tabel 1. 


\section{Tabel 1. Hasil Open Coding Karakteristik Tempat Relaksasi}

\begin{tabular}{|c|c|c|}
\hline No & Kategori & Kata Kunci \\
\hline \multirow{4}{*}{1} & \multirow{4}{*}{ Aksesibilitas } & Lokasi dekat rumah \\
\hline & & Pusat kota \\
\hline & & Transportasi mudah \\
\hline & & Tidak macet \\
\hline \multirow{5}{*}{2} & \multirow{5}{*}{ Nuansa alam } & Alam \\
\hline & & Pohon \\
\hline & & Sejuk \\
\hline & & Hijau \\
\hline & & Ruang terbuka \\
\hline \multirow{5}{*}{3} & \multirow{5}{*}{ Kelengkapan fasilitas } & Serbaguna \\
\hline & & Belanja \\
\hline & & Kuliner \\
\hline & & Toko buku \\
\hline & & Toko pakaian \\
\hline \multirow{3}{*}{4} & \multirow{3}{*}{ Suasana } & Nyaman \\
\hline & & Refreshing \\
\hline & & Latar musik \\
\hline \multirow{4}{*}{5} & \multirow{4}{*}{ Ketenangan } & Tenang \\
\hline & & Sepi \\
\hline & & Sunyi \\
\hline & & Sedikit gangguan \\
\hline \multirow{4}{*}{6} & \multirow{4}{*}{ Kualitas ruang } & Luas \\
\hline & & Rapi \\
\hline & & Bersih \\
\hline & & Pemandangan \\
\hline
\end{tabular}

(Sumber: Hasil analisa, 2020)

Pada tahap selanjutnya, dilakukan analisis frekuensi dengan metode analisis distribusi untuk mengetahui dominansi frekuensi dari setiap kategori. Hasil analisis frekuensi menunjukkan bahwa kategori paling dominan adalah nuansa alam sebesar 34 $(21,79 \%)$ dan kelengkapan fasilitas sebesar 33 (21,15\%). Sementara kategori paling tidak dominan adalah kualitas ruang sebesar 14 (8,97\%) dan aksesibilitas sebesar 19 $(12,18 \%)$. Diagram analisis distribusi frekuensi kategori karakteristik ruang kota sebagai tempat relaksasi dapat diamati pada Diagram 1.

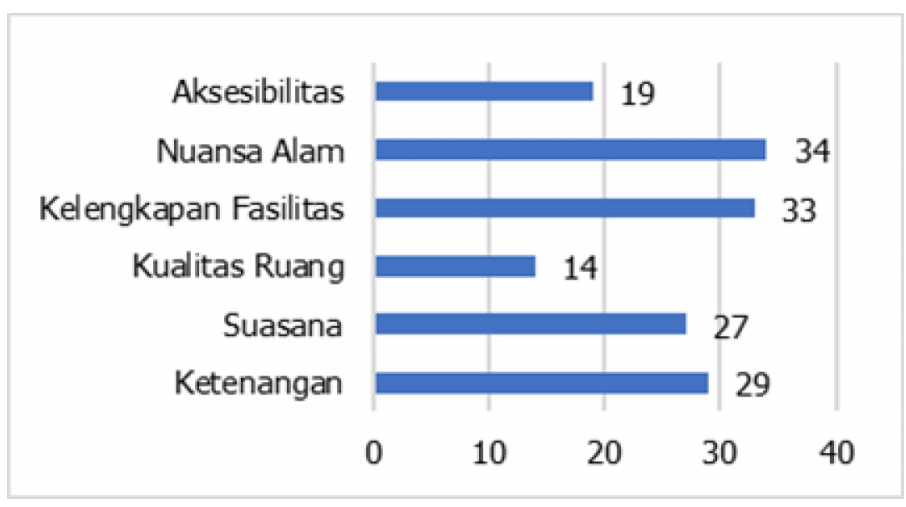

Diagram 1. Analisis Distribusi Frekuensi Kategori Karakteristik Tempat Relaksasi (Sumber: Hasil analisa, 2020) 


\subsubsection{Nuansa Alam}

Keinginan masyarakat kota terhadap ruang yang kaya dengan unsur alam berupa pepohonan, nuansa asri, dan udara sejuk sebagai tempat relaksasi menjadi karakteristik preferensi utama sebesar $21,79 \%$. Lingkungan alam dipercaya memiliki efek restoratif yang lebih tinggi dibandingkan lingkungan terbangun sehingga dapat meningkatkan emosi positif dan suasana hati secara signifikan. Hal ini selaras dengan pernyataan Tyrväinen (2014) yang mengungkapkan bahwa kunjungan jangka pendek ke kawasan bernuansa alam dapat berdampak pada pengurangan tingkat stres. Menikmati pemandangan alam secara langsung dapat mempengaruhi respon psikologis terhadap stres lebih baik dibandingkan aktivitas fisik lainnya di dalam ruangan (Olafsdottir, 2018).

Responden dengan kata kunci pada kategori nuansa alam mengungkapkan dua perspektif yang berbeda terkait alam yang dimaksud yaitu sebagai tempat wisata alami (seperti pantai, air terjun, sungai) dan sebagai ruang hijau kota (seperti taman kota). Mengacu pada skala penelitian yang berada dalam lingkup perkotaan, maka makna alam pada kategori ini adalah lingkungan binaan berupa taman atau ruang terbuka hijau kota.

Van den Berg (2010) dan Alcock (2014) mengungkapkan bahwa area perkotaan yang hijau memiliki keterkaitan erat dengan pengembangan kesehatan psikis yang baik dan berkelanjutan. Taman kota merupakan salah satu ruang terbuka hijau utama perkotaan yang bersifat aktif karena dalam perancangannya ditujukan untuk mendukung kegiatan masyarakat. Menurut Dwiputra (2017), taman kota harus memenuhi beberapa kriteria tertentu untuk dapat berperan maksimal sebagai ruang publik yang efektif sesuai dengan tujuan perancangan.

\subsubsection{Kelengkapan Fasilitas}

Perbedaan persentase frekuensi yang sangat tipis antara kategori nuansa alam $(21,79 \%)$ dan kelengkapan fasilitas $(21,15 \%)$ menunjukkan bahwa tempat dengan fasilitas lengkap juga merupakan salah satu preferensi utama dari masyarakat kota. Kelengkapan fasilitas ini meliputi ketersediaan berbagai jenis barang seperti pakaian, alat rumah tangga, hobi, ataupun makanan. Hal ini secara tidak langsung memperlihatkan bahwa masyarakat kota tidak akan dapat terlepas dari keterikatan terhadap gaya hidup hedonik perkotaan.

Mayoritas responden dengan kata kunci pada kategori kelengkapan fasilitas mengindikasikan mal atau pusat perbelanjaan sebagai perwujudan dari ruang relaksasi yang diharapkan. Dalam gaya hidup hedonik, ketertarikan individu terhadap suatu fasilitas atau barang tidak hanya sebagai pemenuhan kebutuhan semata, namun juga sebagai sarana pelepas stres. Scarpi (2006) menyatakan bahwa pada hedonic shopping, seseorang merasakan pengalaman berbelanja yang dipenuhi fantasi, keingintahuan, dan kegembiraan. Sebagai akibatnya, kebanyakan masyarakat kota mengunjungi mal tidak untuk mencari atau mendapatkan suatu barang, namun untuk berekreasi melalui perasaan senang ketika berbelanja (Natalia, 2014).

Vinarcikova dan Basova (2017) mengungkapkan bahwa ruang publik yang baik dikarakteristikkan dengan keberadaan beragam fasilitas yang dapat memberi kesenangan bagi pengunjungnya. Kualitas fasilitas ruang publik memiliki potensi untuk mempengaruhi emosi pengguna. Vinarcikova dan Basova (2017) juga menyatakan bahwa atribut kelengkapan fasilitas ruang tersebut merupakan kombinasi dari desain dimensi spasial, fisik, fungsional, teknologi, dan faktor lainnya.

\subsubsection{Kualitas Ruang}

Kategori kualitas ruang memiliki frekuensi terendah di antara semua faktor, yaitu sebesar 8,97\%. Hasil ini menunjukkan bahwa mayoritas masyarakat kota tidak mempermasalahkan tingkat kualitas ruang seperti ukuran, warna, kerapihan, kebersihan, 
ataupun pemandangan yang ditawarkan ruang sebagai karakteristik tempat relaksasi yang diharapkan.

\subsubsection{Aksesibilitas}

Kategori aksesibilitas yang meliputi keterjangkauan lokasi dari rumah, letak pada pusat kota, kemudahan transportasi, serta kebebasan dari kemacetan merupakan faktor kedua dengan jumlah persentase frekuensi terendah yaitu sebesar 12,18\%. Hasil ini menunjukkan bahwa sebagian besar masyarakat kota tidak mempermasalahkan letak atau keterjangkauan ruang kota sebagai karakteristik tempat relaksasi yang diharapkan.

\subsection{Kegiatan Relaksasi}

Untuk mengetahui lebih dalam preferensi ruang kota sebagai tempat relaksasi, selain pengumpulan data alasan pemilihan ruang, juga dilakukan pengumpulan data terkait kegiatan yang dilakukan di ruang tersebut. Berdasarkan hasil analisis, didapatkan delapan kategori kegiatan yang dilakukan masyarakat pada tempat relaksasi, yaitu olahraga, interaksi, kuliner, melihat-lihat, rekreasi, istirahat, perbelanjaan, dan produktivitas. Hasil pengkategorian open coding kegiatan di tempat relaksasi dapat diamati pada Tabel 2 .

\section{Tabel 2. Hasil Open Coding Kegiatan pada Ruang Kota sebagai Tempat Relaksasi}

\begin{tabular}{|c|c|c|}
\hline No & Kategori & Kata Kunci \\
\hline \multirow{2}{*}{1} & \multirow{2}{*}{ Olahraga } & Olahraga \\
\hline & & Jogging \\
\hline \multirow{3}{*}{2} & \multirow{3}{*}{ Interaksi } & Kumpul-kumpul \\
\hline & & Ngobrol \\
\hline & & Bercengkrama \\
\hline 3 & Kuliner & Makan \\
\hline \multirow{2}{*}{4} & \multirow{2}{*}{ Melihat-lihat } & Jalan-jalan \\
\hline & & Foto-foto \\
\hline \multirow{2}{*}{5} & \multirow{2}{*}{ Rekreasi } & Bermain \\
\hline & & Nonton \\
\hline \multirow{3}{*}{6} & \multirow{3}{*}{ Istirahat } & Duduk-duduk \\
\hline & & Istirahat \\
\hline & & Beribadah \\
\hline 7 & Perbelanjaan & Belanja \\
\hline \multirow{3}{*}{8} & \multirow{3}{*}{ Produktivitas } & Bekerja \\
\hline & & Belajar \\
\hline & & Browsing \\
\hline
\end{tabular}

(Sumber: Hasil analisa, 2020)

Pada tahap selanjutnya, dilakukan analisis frekuensi dengan metode analisis distribusi untuk mengetahui dominansi frekuensi dari setiap kategori. Hasil analisis frekuensi menunjukkan bahwa kategori kegiatan paling dominan adalah kuliner sebesar $47(23,98 \%)$ dan istirahat sebesar $31(15,98 \%)$. Sementara kegiatan yang paling tidak dominan adalah olahraga sebesar 10 (5,15\%) dan perbelanjaan sebesar 14 (7,22\%). Diagram analisis distribusi frekuensi kategori kegiatan relaksasi dapat diamati pada Diagram 2. 


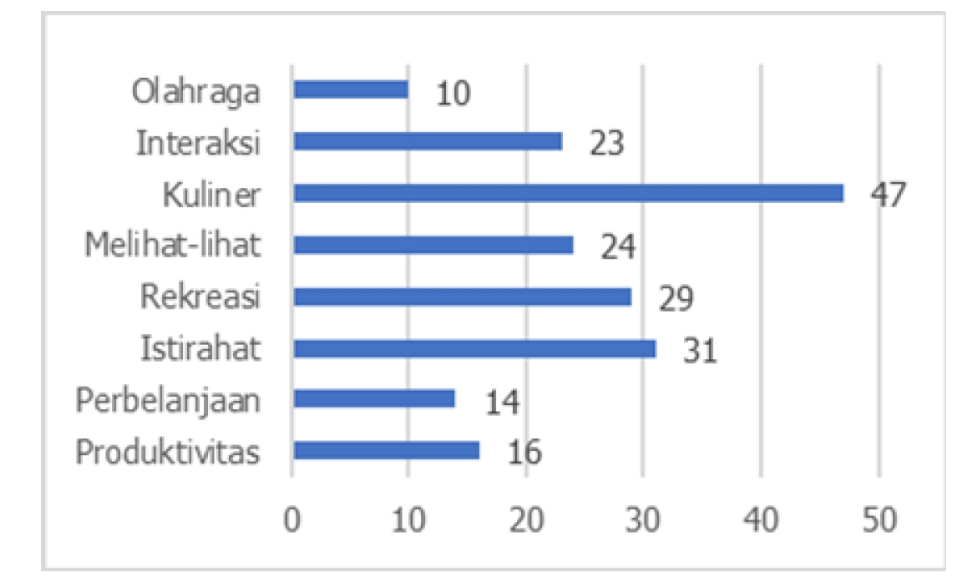

Diagram 2. Analisis Distribusi Frekuensi Kegiatan Relaksasi

(Sumber: Hasil analisa, 2020)

\subsubsection{Kegiatan Kuliner}

Kegiatan kuliner atau makan merupakan kegiatan utama yang paling banyak dilakukan oleh masyarakat kota untuk berelaksasi, yaitu sebesar 23,98\%. Adam dan Epel (2007) dalam Asiah (2015) menyatakan bahwa perilaku makan merupakan integrasi antara sistem saraf pusat, pusat emosi di otak, dan hormon yang dikeluarkan oleh saluran pencernaan. Tingkat stres yang mempengaruhi pusat emosi di otak secara langsung akan berpengaruh terhadap perilaku makan (Choi, 2020). Hal ini berdampak pada bangkitnya rasa lapar dan munculnya keinginan untuk makan.

Kecenderungan seseorang untuk makan bukan karena kebutuhan, melainkan karena dorongan hati atau emosi disebut dengan emotional eating. Menurut Asiah (2015), dorongan tersebut seringkali merupakan penghiburan bagi diri di saat seseorang mengalami stres, depresi, panik, dan kecemasan. Ditinjau dari segi kesehatan, Sominsky dan Spencer (2014) menyatakan bahwa ketika seseorang mengalami stres, tubuh mengeluarkan stimulus glucocorticoid yang mempengaruhi perilaku makan. Tahir (2016) juga menyatakan bahwa perubahan nafsu dan perilaku makan ini merupakan bentuk perlindungan tubuh untuk menekan rasa stres.

\subsubsection{Kegiatan Istirahat}

Kegiatan istirahat yang dimaksud merupakan kegiatan pasif dengan sedikit stimulus, seperti duduk-duduk ataupun beribadah untuk kebutuhan rohani. Kegiatan istirahat merupakan kegiatan paling dominan ke-dua yang dilakukan oleh masyarakat kota untuk berelaksasi yaitu sebesar 15,98\%.

Hal ini disebabkan sumber stres masyarakat perkotaan umumnya dipengaruhi oleh faktor banyaknya stimulus yang diterima dari hiruk pikuk kota atau disebut dengan overload (Ellison, 1992). Oleh karena itu, salah satu upaya untuk mengatasi tingkat stres dalam kota adalah dengan mengurangi sumber stres dan stimulus yang masuk. Vancouver Island Health Authority (2015) menyatakan bahwa terdapat empat kuadran fokus manusia yang terdiri dari fisik, emosional, mental, dan spriritual. Kegiatan relaksasi pasif seperti istirahat, meditasi, dan beribadah diketahui dapat meningkatkan dua dari empat aspek tersebut yaitu mental dan spiritual.

\subsubsection{Kegiatan Olahraga}

Kegiatan olahraga merupakan kegiatan relaksasi aktif yang dilakukan untuk memenuhi kebutuhan aspek fisik individu Kegiatan ini dapat meliputi beragam aktivitas yang melibatkan pergerakan badan secara fisik dan merupakan salah satu medium penyalur stres (Vancouver Island Health Authority, 2015). Namun meskipun olahraga 
diketahui dapat membantu mengurangi ketegangan yang dialami seseorang, kegiatan ini tidak menjadi pilihan utama masyarakat kota untuk melepas stres. Hasil ini terlihat dari persentase frekuensi kegiatan olahraga sebagai kegiatan paling tidak dominan untuk berelaksasi yaitu sebesar $5,15 \%$.

\subsubsection{Kegiatan Perbelanjaan}

Kegiatan perbelanjaan menjadi kegiatan paling tidak dominan ke-dua untuk berelaksasi yaitu sebesar 7,22\%. Jika dikaitkan dengan kelengkapan fasilitas yang menjadi kategori dominan ke-dua dari karakteristik tempat relaksasi, melalui analisis kegiatan ini diketahui bahwa kegiatan utama yang dilakukan oleh masyarakat kota di mal untuk berelaksasi bukanlah berbelanja, melainkan berupa kegiatan kuliner, rekreasi, dan melihat-lihat.

\subsection{Korespondensi Karakteristik Tempat dan Kegiatan Relaksasi}

Untuk mengetahui keterkaitan antara karakteristik tempat relaksasi dengan kegiatan relaksasi, pada tahap berikutnya dilakukan axial coding berupa analisis korespondensi. Analisis ini dilakukan dengan menggunakan metode ward hierarchical clustering. Hasil analisis korespondensi karakteristik tempat dan kegiatan relaksasi dapat diamati pada Diagram 3.
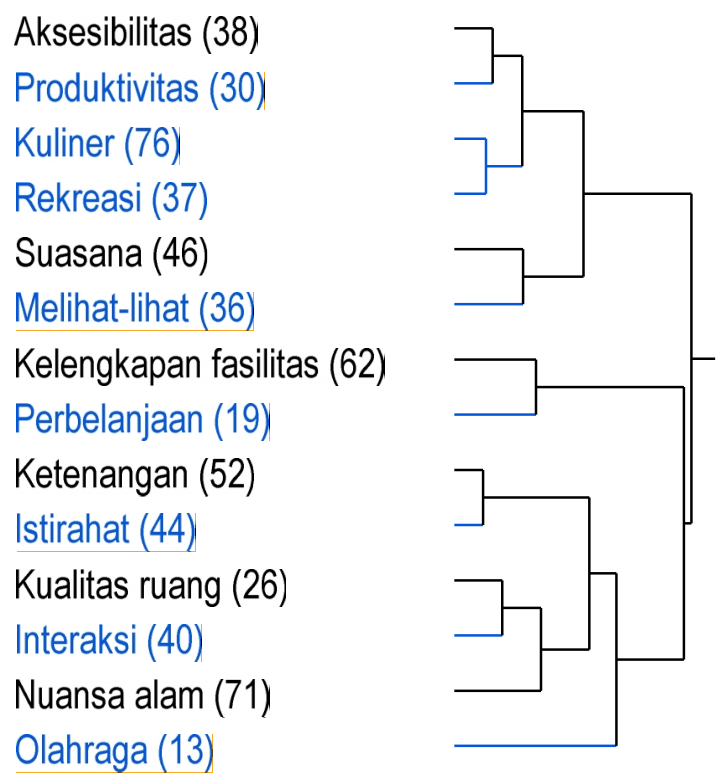

Diagram 3. Analisis Korespondensi Karakteristik Tempat dan Kegiatan Relaksasi ( $\mathrm{p}=$ 0.1252 )

(Sumber: Hasil analisa, 2018)

Hasil analisis korespondensi (coincidence) antara karakteristik tempat relaksasi dengan kegiatan relaksasi memiliki signifikansi sebesar $\mathrm{p}=0.1252$. Nilai signifikansi ini menunjukkan bahwa keterkaitan antar dua variabel tersebut memiliki hubungan yang rendah atau weakly significant. Meskipun memiliki nilai signifikansi rendah, hasil korespondensi menunjukkan adanya kecenderungan pengelompokan antara karakteristik pemilihan ruang kota sebagai tempat relaksasi dengan kegiatan di dalamnya. Pengelompokan ini dapat dibagi menjadi tiga kelompok utama sebagai berikut. 
Responden yang memilih ruang kota dengan aksesibilitas tinggi sebagai tempat relaksasi cenderung melakukan kegiatan relaksasi terkait produktivitas seperti belajar atau bekerja. Selain kegiatan utama tersebut, kelompok ini juga melakukan kegiatan lainnya seperti kuliner dan rekreasi. Sementara responden yang memilih ruang kota dengan suasana nyaman sebagai tempat relaksasi cenderung melakukan kegiatan melihat-lihat untuk berelaksasi. Perwujudan ruang kota yang termasuk dalam kelompok ini adalah coworking space yang terletak di pusat kota dan mudah dijangkau.

Responden yang memilih ruang kota dengan kelengkapan fasilitas sebagai tempat relaksasi cenderung melakukan kegiatan berupa perbelanjaan. Perwujudan ruang kota yang termasuk dalam kelompok ini adalah mal, lifestyle center, dan pusat perbelanjaan.

Responden yang memilih ruang kota yang sepi, jauh dari gangguan, dan memiliki tingkat ketenangan tinggi sebagai tempat relaksasi cenderung melakukan kegiatan berupa istirahat atau restorasi untuk melepas stres. Sementara kegiatan interaksi lebih banyak dilakukan pada tempat yang memiliki kualitas ruang yang baik dan bernuansa alam. Selain sebagai tempat beristirahat dan berinteraksi, tempat tersebut juga dapat dipergunakan untuk kegiatan olahraga. Perwujudan ruang kota yang termasuk dalam kelompok ini adalah taman kota.

\subsection{Model Hipotesis}

Pada tahap selanjutnya, dilakukan selective coding berupa penyusunan model hipotesis berdasarkan pola kedekatan antar karakteristik tempat relaksasi dan kegiatan relaksasi yang diperoleh pada tahap axial coding. Hasil analisis pola kedekatan dapat diamati pada Diagram 4.
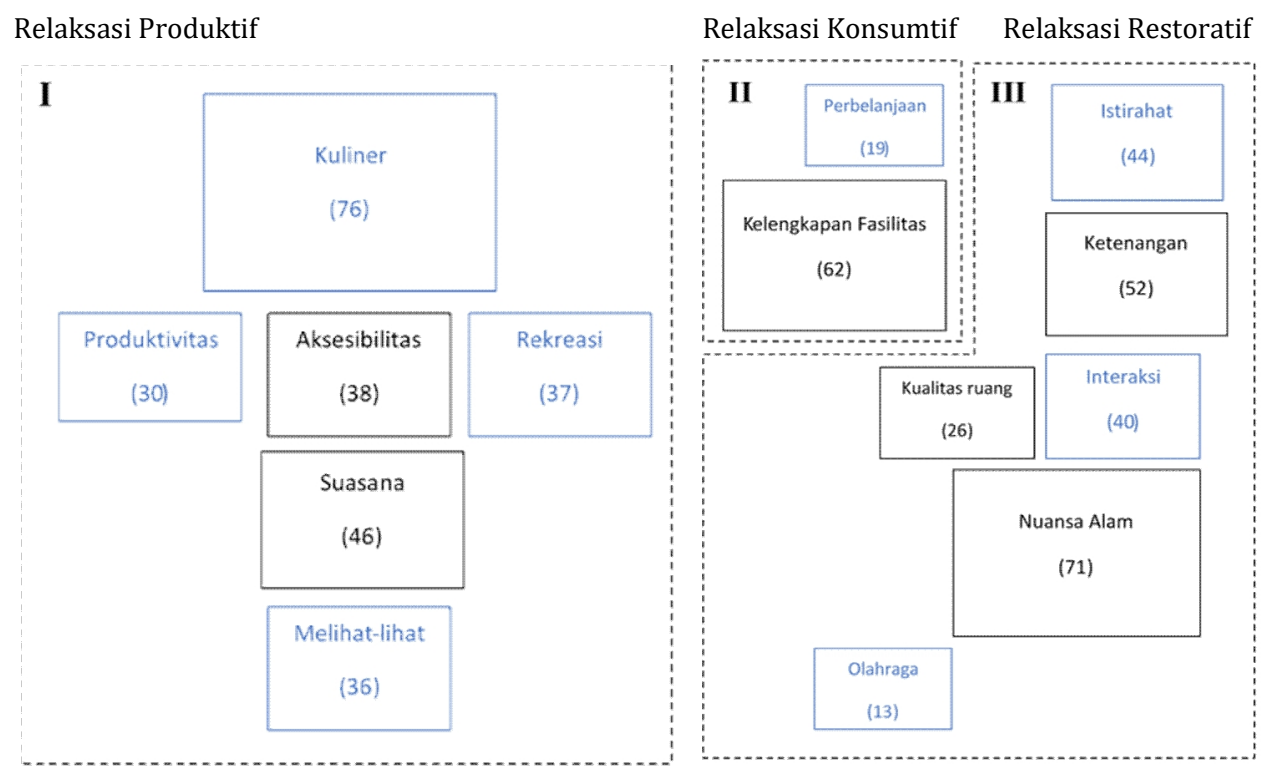

Diagram 4. Analisis Pola Kedekatan Tempat Relaksasi dan Kegiatan Relaksasi

(Sumber: Hasil analisa, 2020)

Pola kedekatan tempat dan kegiatan relaksasi terdiri dari tiga kelompok utama yaitu relaksasi produktif, relaksasi konsumtif, dan relaksasi restoratif. Relaksasi produktif merupakan rangkaian kegiatan yang meliputi kuliner, rekreasi, melihat-lihat, dan produktivitas. Kombinasi kegiatan ini dapat dikelompokkan sebagai coworking space atau ruang kerja bersama. Menurut Merkel (2015), masyarakat umumnya mencari coworking space yang menggabungkan suasana ruang kerja, relaksasi, dan rumah (work, leisure, and home) untuk menghilangkan kebosanan dalam beraktivitas. Ruang ini juga 
memiliki batas yang memungkinkan terciptanya keseimbangan antara aktivitas relaksasi dan produktif (Neff, 2005). Relaksasi produktif cenderung terjadi pada tempat yang dapat diakses dengan mudah dan memiliki suasana nyaman, menyegarkan, serta dilengkapi dengan latar musik.

Relaksasi konsumtif merupakan rangkaian kegiatan yang terkait dengan perbelanjaan. Bagi sebagian besar masyarakat kota, kegiatan perbelanjaan telah menjadi sebuah gaya hidup yang tidak dapat dipisahkan. Menurut Levi (2009), gaya hidup perbelanjaan atau shopping lifestyle merupakan gaya hidup yang mengacu pada bagaimana sikap seseorang dalam melakukan kegiatan pembelian dan menghabiskan uang. Keputusan untuk melakukan kegiatan tersebut dipengaruhi oleh faktor personal seperti latar belakang sosial, nilai yang dianut, lingkaran pertemanan, ataupun lingkungan tempat tinggal (Kim dan Kang, 2001). Dalam perencanaan kota, ruang untuk mengakomodasi kegiatan perbelanjaan ini ditandai dengan kelengkapan fasilitas di dalamnya.

Relaksasi restoratif merupakan rangkaian kegiatan yang meliputi istirahat, interaksi, dan olahraga. Kegiatan restoratif dimaksudkan untuk merubah suasana hati dengan menenangkan dan mengistirahatkan pikiran individu dari tekanan ataupun emosi negatif. Interaksi dengan lingkungan diketahui memberikan pengaruh signifikan terhadap perubahan emosi seseorang, khususnya pada tempat yang memiliki keterikatan dengan individu (Ratcliffe \& Korpela, 2016). Oleh karenanya, ruang relaksasi restoratif ditandai dengan karakteristik utama berupa nuansa alam, ketenangan, dan kualitas ruang yang baik.

\section{Simpulan}

Preferensi masyarakat dalam memilih ruang relaksasi terdiri dari enam karakteristik (kriteria) utama, yang secara berurutan dari paling dominan adalah nuansa alam, kelengkapan fasilitas, ketenangan, suasana, aksesibilitas, dan kualitas ruang. Sementara kecenderungan kegiatan yang dilakukan untuk berelaksasi secara terurut adalah kegiatan kuliner, istirahat, rekreasi, melihat-lihat, interaksi, produktivitas, perbelanjaan, dan olahraga. Sehingga perancangan ruang kota yang dianggap paling efektif sebagai tempat relaksasi adalah ruang yang memiliki nuansa alam yang kuat, dapat mengakomodasi berbagai fasilitas khususnya kuliner, dan memiliki suasana tenang untuk beristirahat.

Penelitian ini memiliki nilai keaslian tinggi karena dilakukan melalui pendekatan grounded theory. Namun, data yang dikumpulkan dengan metode non-random sampling serta jumlah responden yang terbatas menjadikan data kurang bersifat representatif. Untuk meningkatkan reliabilitas dan tingkat generalisasi data, sebaiknya pengumpulan data dilakukan melalui metode random sampling. Hal ini dikarenakan tingkat preferensi seseorang terhadap ruang kota sebagai tempat relaksasi juga dapat dipengaruhi oleh latar belakang sosial ekonomi berupa usia dan pekerjaan, latar belakang geografi berupa lokasi tempat tinggal, dan sebagainya. Sehingga data akan menjadi lebih representatif jika sampel meliputi setiap golongan masyarakat yang beragam tersebut.

Selain itu, diusulkan pula beberapa studi lanjutan berupa peninjauan terhadap relaxant kota untuk mengurangi tingkat stres di perkotaan serta penerapan stress free city untuk merancang kota yang memiliki tingkat stres seminimal mungkin.

\section{Ucapan Terima Kasih}

Ucapan terima kasih penulis sampaikan kepada Bapak Dr. Eng. Hanson Endra Kusuma, ST., M. Eng selaku dosen pada Program Studi Magister Arsitektur di Institut Teknologi Bandung atas pengajaran dan bimbingan yang diberikan dalam pengerjaan 
artikel ini. Ucapan terima kasih juga penulis sampaikan kepada Laras Primasari, ST., MPD., MUDD selaku asisten akademik yang juga telah membantu dan memberi masukan selama pengerjaan artikel ini.

\section{Daftar Pustaka}

Adli, Mazda. (2011). Urban Stress and Mental Health. LSECities Alfred Herrhausen Gesellschaft.

Alcock, Ian, dkk. (2014). Longitudinal Effects on Mental Health of Moving to Greener and Less Green Urban Areas. Environmental Science \& Technology, 48(2), 1247-1255.

Asiah, Nur. (2015). Psikologi Gizi. Jakarta: Universitas Yarsi.

Choi, Jinkyung. (2020). Impact of Stress Levels on Eating Behaviours among Collehe Students. Nutrients 12, 1241.

Corbin, J., \& Strauss, A. (2008). Basics of Qualitative Research: Techniques and Procedures for Developing Grounded Theory (3rd ed.). Thousand Oaks, CA: Sage.

Creswell, John, W. (2007). Qualitative Inquiry and Research Design: Choosing Among Five Approaches. California: Sage Publications, Inc.

Djikstra, K. (2009). Understanding Healing Environments: Effects of Physical Environmental Stimuli on Patiens' Effects of Health and Well-Being. Netherlands: University of Twente.

Dwiputra, Ivan D. \& Ardiani, Nissa A. (2017). Preferensi Masyarakat dalam Memilih Karakteristik Taman Kota Berdasarkan Motivasi Kegiatan. Prosiding Temu Ilmiah IPLBI 2017 Lhokseumawe.

Dye, C. (2008). Health and Urban Living. Science 319, 766-769.

Ellison, Craig W. \& Maynard, Edward S. (1992). Healing for the City. Michigan: Zondervan Publishing House.

Faehnle, M., dkk. (2014). How Can Residents' Experiences Inform Planning of Urban Green Infrastructure? Case Finland. Landscape and Urban Planning, 130, 171-183.

Fehr, Rainer \& Capolongo, Stefano. (2016). Healing Environment and Urban Health. Epidemiol Prev, 40(3-4), 151-152.

Gruebner, Oliver, dkk. (2017). Cities and Mental Health. Deutsches Arzteblatt International, 114(8), 121-127. https://doi.org/10.3238/arztebl.2017.0121.

Kaplan, S. (1995). The Restorative Benefits of Nature: Toward an Integrative Framework. Journal of Environmental Psychology, 15, 169-82.

Kim, Youn-Kyung, \& Kang, Jikyeong, (2001). The Effects of Ethnicity and Product on Purchase Decision Making. Journal of Advertising Research, 39-48.

Levy, M \& Weitz, B.A. (2009). Retailing Manajemen 7 Edition. New York: Mc Graw Hill.

Merkel, J. (2015). Coworking in the City. Ephemera, 15(2), 121-139.

Natalia, Tri W. \& Kusuma, Hanson E. (2014). Hubungan antara Motivasi Berbelanja dan Preferensi Shopping Mal di Kota Bandung. Prosiding Temu Ilmiah IPLBI 2014 Bandung.

Neff, G. (2005). The Changing Place of Cultural Production: The Location of Social Networks in a Digital Media Industry. The Annals of the American Academy of Political and Social Science, 597(1), 134-152.

Olafsdottir, Gunnthora, dkk. (2018). Health benefits of Walking in Nature: A Randomized Controlled Study Under Conditions of Real-Life Sress. Environment and Behavior, 127.

Peen, J., dkk. (2010). The Current Status of Urban-Rural Differences in Psychiatric Disorders. Acta Psychiatr Scand, 121(2), 84-93.

Ratcliffe, E. \& Korpela, K. (2016). Memory and Place Attachment as Predictors of Imagined Restorative Perceptions of Favourite Places. Journal of Environmental Psychology. 
Scarpi, D. (2006). Fashion Stores between Fun and Usefulness. Journal of Fashion Marketing and Management, 10(1), 7-24.

Sominsky, L. \& Spenser, S.J. (2014). Eating Behaviour and Stress. Frontiers in Psychology 5(434).

Tahir, Urooj. (2016). Stress and Eating Behaviour. Advances in Obesity, Weight Management \& Control 4(4).

Tyrväinen, Liisa, dkk. (2014). The Influence of Urban Green Environments on Stress Relief Measures: A Field Experiment. Journal of Environmental Psychology 38, 1-9.

United Nations, Department of Economic and Social Affairs, Population Division. (2018). World Urbanization Prospects: The 2018 Revision, Daring Edition.

Van den Berg, A. E., dkk. (2010). Green Space as A Buffer Between Stressful Life Events and Health. Soc Sci Med, 70(8), 1203-1210

Vancouver Island Health Authority. (2015). Cognitive Behavioural Skills Manual. Victoria: Island Health.

Vinarcikova, J. \& Basova, S. (2017). Fun and Relax - Attributes of the Vital Contemporary Urban Public Spaces. International Multidisciplinary Scientific Conference on Social Sciences and Arts / SGEM Vienna 2017. 